\title{
Peran Guru Dalam Pengembangan Karakter Pada Siswa Kelas III SD Negeri 071154 Anaoma Kecamatan Alasa
}

\author{
Yuniman Hulu \\ SD Negeri 071154 Anaoma \\ yunimanhulu28@gmail.com
}

\begin{abstract}
Abstrak
Penelitian ini bertujuan untuk mendeskripsikan peran guru dalam mengembangkan karakter disiplin pada siswa kelas III SD Negeri 071154 Anaoma Kecamatan Alasa. Metode penelitian yang digunakan dengan metode kualitatif dengan jenis penelitian studi kasus. Teknik pengumpulan data dalam penelitian ini menggunakan teknik observasi, wawancara dan dokumentasi yang dianalisis dengan langkah yaitu reduksi data, display/penyajian data dan menarik kesimpulan. Hasil penelitian menunjukkan bahwa, peran guru dalam membentuk karakter pada siswa kelas III SD Negeri 071154 Anaoma Kecamatan Alasa yaitu guru menjadi teladan, dinamisator, serta evaluator. nilai-nilai karakter yang terbentuk pada siswa kelas III SD Negeri 071154 Anaoma Kecamatan Alasa yaitu religius, jujur, disiplin, tanggung jawab, kerja keras, kreatif, mandiri, rasa ingin tahu, gemar membaca, toleransi, cinta damai, demokratis, komunikatif, menghargai prestasi, nasionalisme, cinta tanah air, peduli lingkungan, peduli sosial, dan integritas; faktor pendukung dalam membentuk karakter siswa adalah guru sudah paham secara benar mengenai konsep dan aplikasi pendidikan karakter, sarana dan prasarana sekolah yang menunjang dalam pembelajaran dan proses pendidikan karakter, dan guru berperan aktif dalam pendidikan karakter sedangkan faktor penghambatnya adalah peserta didik yang mempunyai tabiat yang kurang baik dan faktor keluarga, faktor lingkungan masyarakat yang kurang mendukung.
\end{abstract}

Kata Kunci: Peran Guru, Pendidikan Karakter, Sekolah Dasar

\section{Pendahuluan}

Penataan kembali pendidikan karakter bangsa harus segera dilakukan. Hal ini disebabkan oleh berbagai krisis multi dimensi yang dihadapi oleh bangsa Indonesia. Krisis multi dimensi selain disebabkan oleh infrastruktur kebangsaan, kenegaraan, dan kemasyarakatan yang rawan krisis, juga disebabkan karena adanya dinamika perubahan tatanan dunia dengan semakin menguatnya arus globalisasi (arus orang, modal, barang, jasa, informasi, gaya hidup, nilai-nilai, budaya, lintas batas negara). Globalisasi tidak hanya membawa dampak positif tetapi juga membawa dampak negatif. Kompetisi, integrasi, dan kerjasama adalah dampak positif globalisasi. Lahirnya generasi instan (generasi now, sekarang, langsung, bisa menikmati keinginan tanpa proses perjuangan dan kerja keras), korupsi, dan asusila, bahkan seks bebas adalah sebagian dampak negatif globalisasi (Fitri, 2012) 
Akhirnya, karakter anak bangsa berubah menjadi rapuh, mudah diterjang ombak, terjerumus dalam tren budaya yang melengahkan, dan memikirkan akibat yang ditimbulkan. Prinsip-prinsip moral, budaya bangsa, dan perjuangan hilang dari karakteristik mereka. Inilah yang menyebabkan dekadensi moral serta hilangnya kreatifitas dan produktivitas bangsa. Sebab ketika karakter suatu bangsa rapuh maka semangat berkreasi dan berinovasi dalam kompetisi yang ketat akan mengendur. Oleh karena itu perlu diterapkan nilai-nilai kedisiplinan di dalam semua lembaga pendidikan sebagai social control yang diharapkan.

Dalam Undang-undang Nomor 14 Tahun 2015 tentang Guru dan Dosen Pasal 1 disebutkan bahwa "guru adalah pendidik profesional dengan tugas utama mendidik, mengajar, membimbing, mengarahkan, melatih, menilai, dan mengevaluasi peserta didik pada pendidikan formal, pendidikan dasar, dan pendidikan menengah". Seiring zaman dan perkembangan ilmu pengetahuan, peran guru juga menjadi beragam. Peran guru tidak hanya sebatas sebagai pengajar dan pendidik saja, tetapi juga berperan sebagai inspirator, motivator, konselor, dan sahabat. Bahkan mungkin sebagai orang tua pengganti orang tua mereka di rumah. Oleh karena itu, peran guru sangatlah besar karena guru merupakan salah satu pihak yang bertanggungjawab atas pondasi yang dibuat dalam pembentukan karakter peserta didik.

Dalam Kamus Umum Bahasa Indonesia, Poerwadarminta (2006) mengartikan kata membentuk sama halnya dengan mendidik dan mengajari, dengan kata lain memperbaiki kelakuan orang. Dengan kata lain, bahwa kata membentuk adalah segala upaya untuk membimbing dan mengarahkan kepada suatu hal. Pembentukan tingkah laku dan karakter seseorang dimulai sejak ia lahir, berjalan seiring dengan perkembangan dan penyesuaiannya terhadap lingkungan sosial. Namun, tidak setiap anak dapat melewati masa ini dengan baik, sehingga munculah berbagai masalah tingkah laku dan karakter pada anak. Driyarkara (Suparno, 2015:30) menjelaskan bahwa "karakter seseorang itu ada yang baik dan yang tidak baik. Tugas pendidikan karakter adalah mengembangkan karakter yang baik agar tetap dilakukan dan menghilangkan karakter yang tidak baik supaya tidak terulang kembali.”

Pendidikan di Sekolah Dasar (SD) merupakan pendidikan yang sangat penting bagi peserta didik dalam hal pendidikan karakter. Anak SD merupakan anak yang sedang berkembang dan merupakan masa yang tepat untuk menanamkan karakter-karakter yang baik. Usia anak Sekolah Dasar (6-12 tahun) merupakan tahap penting dalam pendidikan karakter karena pada usia tersebut anak sedang mengalami perkembangan fisik dan motorik tak terkecuali perkembangan kepribadian, watak emosional, intelektual, bahasa, budi pekerti, dan moralnya yang bertumbuh pesat. Jika pada masa ini penanaman nilainilai karakter dengan secara sempurna, maka akan menjadi pondasi dasar dan kepribadian anak ketika dewasa kelak. Para insan pendidik seperti guru, orang tua, staff sekolah, dan masyarakat diharapkan perlu menyadari betapa pentingnya pendidikan karakter sebagai sarana pembentuk pedoman perilaku, pengayaan nilai individu dengan cara menjadi figur keteladanan bagi anak didik serta mampu menciptakan lingkungan yang kondusif bagi proses pertumbuhannya. Dari uraian di atas, tujuan dalam penelitian ini yaitu untuk mengetahui peran Guru Kelas III SD Negeri 071154 Anaoma Kecamatan Alasa dalam pelaksanaan pendidikan karakter.

\section{Metode}

Untuk mengkaji permasalahan pada uraian di atas, dilakukan dengan berdasarkan masalah dan tujuan penelitian, maka pendekatan yang digunakan dalam penelitian ini adalah penelitian pendekatan kualitatif dengan strategi deskriptif analitik, yaitu metode yang menggambarkan keadaan yang sedang berlangsung pada saat penelitian dilakukan, berdasarkan fakta yang ada (Furqon, 1997:10). Metode 
deskriptif tidak hanya terbatas pada pengumpulan dan penyusunan data. Metode desktiptif mempunyai ciri-ciri memusatkan pada pemecahan masalah yang ada dan aktual, data dikumpulkan, disusun, dijelaskan kemudian dianalisis (Surahmad, 1988:139). Sumber data yang digunakan untuk mendapat informasi tentang objek yang diteliti yaitu Guru Kelas III SD Negeri 071154 Anaoma Kecamatan Alasa yang berjumlah empat orang dan peserta didik, adapun peserta didik yang penulis jadikan sampel adalah 5 orang peserta didik dengan menggunakan teori purpossive random sampling. Purposive sampling dikenal juga dengan sampling pertimbangan. Purposive sampling ialah teknik sampling yang digunakan peneliti jika peneliti mempunyai pertimbangan-pertimbangan tertentu di dalam pengambilan sampelnya atau penentuan sampel untuk tujuan tertentu. oleh karena itu, sampling ini cocok untuk studi kasus yang mana aspek dari kasus tunggal yang representatif diamati dan dianalisis (Sudarno, 2013:176). Sedangkan dalam penelitian ini jenis data yang digunakan adalah kata-kata, tindakan, sumber data tertulis dan foto. Teknik pengumpulan data yang digunakan adalah observasi, wawancara, dan dokumentasi hal ini senada dengan Moleong yang mengatakan dalam penelitian kualitatif metode pengumpulan data yaitu pengamatan (observasi), wawancara, dan dokumentasi (Moloeng, 2005:174). Sedangkan analisis data yang digunakan adalah reduksi data, penyajian data, dan penarikan kesimpulan (Suprayogo, 2001:93).

\section{Hasil}

Guru Kelas III SD Negeri 071154 Anaoma Kecamatan Alasadapat menjadi teladan yang baik untuk para siswanya, yang ditandai dengan mampu melaksanakan perannya sebagai seorang sosok teladan yang baik. Sosok guru Kelas III SD Negeri 071154 Anaoma Kecamatan Alasamampu menjalankan perannya sebagai guru inspirator bagi peserta didiknya. Guru di Kelas III SD Negeri 071154 Anaoma Kecamatan Alasamenjalankan perannya dengan dengan baik, dan melakukan berbagai macam cara untuk memotivasi peserta didiknya sehingga peserta didiknya memiliki semangat berprestasi. Guru di Kelas III SD Negeri 071154 Anaoma Kecamatan Alasa dalam menjalankan perannya sebagai sosok dinamisator belum sepenuhnya maksimal sehingga perlu ditingkatkan lagi dalam menjalankan perannya sebagai sosok dinamisator. Sosok guru sebagai evaluator sangat melekat di hati para guru di Kelas III SD Negeri 071154 Anaoma Kecamatan Alasa, pembelajaran dan pelayanan pendidikan semakin hari semakin baik dan ada peningkatan.

Berdasarkan pada paparan data penelitian dapat dikemukakan beberapa temuan penelitian diantaranya yaitu bahwa guru memiliki peran penting dalam membentuk karakter siswa karena guru adalah orang yang paling menentukan berhasil atau tidaknya proses pembelajaran maupun pendidikan karakter. Karakter yang terbentuk pada siswa di Kelas III SD Negeri 071154 Anaoma Kecamatan Alasa adalah religius, jujur, toleransi, disiplin, kerja keras kreatif, mandiri, demokratis, rasa ingin tahu, semangat kebangsaan atau nasionalisme, cinta tanah air, menghargai prestasi, komunikatif, cinta damai, gemar membaca, peduli lingkungan, peduli sosial, dan tanggung jawab.

Penelitian ini juga menemukan bahwa pengembangan nilai-nilai karakter melalui setiap mata pelajaran, melalui pengembangan diri, dan melalui budaya sekolah. Ini artinya, gurulah yang paling berperan dalam membentuk karakter siswa karena guru yang paling banyak bertatap muka dengan siswanya. Pada pengembangan nilai-nilai karakter melalui setiap mata pelajaran, yang perlu diperhatikan guru adalah satu aktivitas belajar dapat digunakan untuk mengembangkan kemampuan dalam ranah kognitif, afektif, dan pikomotor yang dalam hal itu peserta didik perlu mengetahui pergantian suatu nilai yang sedang mereka tumbuhkan pada diri mereka sendiri. Pada pengembangan nilai-nilai karakter melalui pengembangan diri dapat dilakukan oleh guru dengan memahami 
karakter pada setiap peserta didik kemudian mengenali bakatnya dan selanjutnya menyalurkan bakatnya ke dalam kegiatan pengembangan diri. Pada pengembangan nilai-nilai karakter melalui budaya sekolah dengan membiasakan jabat tangan dengan guru ketika di depan pintu gerbang sekolah, sholat dzuhur secara berjamaah, Jumat bersih, dan lomba kebersihan antar kelas yang biasa dilakukan setiap satu bulan sekali. Berkaitan dengan pengembangan nilai-nilai karakter melalui setiap mata pelajaran, berdasarkan data dokumentasi dapat ditemukan ada kesamaan dan struktur di dalamnya antara RPP tanpa muatan karakter dengan RPP bermuatan karakter, namun dalam implementasinya tetap menanamkan karakter dalam pembelajaran. Dalam kenyataan, walaupun masing-masing guru memiliki pendapat yang sama tentang perencanaan pengajaran, namun dalam realisasinya berbeda. Hal itu tampak dari penerapan di dalam kelas, utamanya dalam aplikasi metode pembelajaran. Semua guru menyusun kegiatan secara sistematis berupa RPP, namun dalam penerapan di kelas tidak jarang tidak sesuai dengan apa yang dituliskan dalam RPP. Banyak faktor yang mempengaruhi fakta tersebut, bisa jadi karena waktu, kemampuan guru, keadaan siswa, media dan suasana dalam kelas.

Faktor pendukung guru dalam membentuk karakter melalui nilai-nilai kedisiplinan pada siswa Kelas III SD Negeri 071154 Anaoma Kecamatan Alasa adalah a) Adanya kontrol dari Kepala Sekolah secara langsung antara lain 1) Dengan terlibat langsung, 2) Dengan melalui evaluasi rutin, b) Adanya peran aktif dari para guru, c) Adanya peran aktif dari orang tua siswa, d) Kesadaran para siswa, dan e) Adanya kekompakan antara kepala sekolah dengan para guru. Sedangkan faktor penghambat yang dirasakan guru adalah lebih kepada muncul dari dirinya sendiri, bukan dari siswanya. Faktor tersebut yaitu tugas sampingan, waktu, emosi, dan kurang konsistennya apa yang diajarkan dengan kenyataan. Temuan Penelitian

\section{Pembahasan}

Berdasarkan pada paparan data penelitian dapat dikemukakan beberapa temuan penelitian yaitu guru memegang peranan penting dalam membentuk karakter siswa. Guru kelas adalah orang yang paling lama bertatap langsung dengan siswa selama di sekolah. Dalam hal ini, guru harus mampu menempatkan diri sebagai pengarah dan pembina, pengembang bakat dan kemampuan anak didik kearah titik maksimal (Arifin, 2003:118). Untuk menguatkan posisinya, ada beberapa standar kualitas kepribadian yang harus dipenuhi oleh pendidik, yaitu tanggung jawab dan wibawa (Mulyasa, 2008). Apapun yang dilakukan guru sedikit banyak mempengaruhi pembentukan karakter pada siswanya.

Penelitian ini juga menemukan bahwa dalam membentuk karakter siswa, selain melalui pembelajaran dalam kegiatan belajar mengajar tapi juga melalui budaya sekolah. Dalam pembelajaran, guru berusaha untuk mengambil nilai moral dari sudut pandang yang sekiranya dapat dikaitkan dengan materi yang sedang dipelajari. Kegiatan pembelajaran dimanfaatkan guru untuk sebanyak-banyaknya menanamkan nilai-nilai karakter pada siswa. Guru banyak menanamkan nilai keadilan untuk membuat siswa peduli dengan nilai-nilai moral, cara tersebut jarang digunakan guru. Berkaitan dengan pembentukan karakter melalui pembelajaran, ditemukan pula dokumentasi berupa silabus dan RPP yang memuat nilai-nilai karakter yang akan ditanamkan pada siswa. Dalam hal ini, tugas guru sebagai pengajar bertugas merencanakan. program pengajaran, melaksanakan program pengajaran serta mengakhiri dengan pelaksanaan penilaian setelah program dilakukan (Sukmadinata, 2007:252).

Selain guru, penanaman karakter juga menjadi tanggung jawab bersama oleh seluruh warga sekolah, menurut (Sudjarwo, 2015:96) bahwa keberhasilan pendidikan karakter ini tidak hanya menjadi tanggung jawab pendidik di sekolah saja, akan tetapi 
juga tanggung jawab orang tua di rumah sebagai lembaga pendidikan informal. Sedangkan, pembentukan karakter melalui budaya sekolah adalah membiasakan siswa untuk disiplin, peduli dengan diri sendiri, orang lain, dan lingkungan. Budaya sekolah yang ada di Kelas III SD Negeri 071154 Anaoma Kecamatan Alasa untuk membentuk karakter siswa adalah Jum'at sehat, cuci tangan, membiasakan berbaris ketika hendak masuk kelas dan pulang sekolah sambil memeriksa kebersihan dan kerapian, memberi hormat kepada guru, mengajarkan siswa untuk beribadah kepada Tuhan yang Maha Esa.

\section{Kesimpulan}

Peran guru dalam pendidikan karakter sangat penting dalam membentuk karakter siswa; nilai-nilai karakter yang terbentuk pada siswa di Kelas III SD Negeri 071154 Anaoma Kecamatan Alasa itu religius, jujur, disiplin, tanggung jawab, kerja keras, kreatif, mandiri, rasa ingin tahu, gemar membaca, toleransi, cinta damai, demokratis, komunikatif, menghargai prestasi, nasionalisme, cinta tanah air, peduli lingkungan, peduli sosial, dan integritas; faktor pendukung dalam membentuk karakter siswa adalah guru sudah paham secara benar mengenai konsep dan aplikasi pendidikan karakter, sarana dan prasarana sekolah yang menunjang dalam pembelajaran dan proses pendidikan karakter, dan guru berperan aktif dalam pendidikan karakter sedangkan faktor penghambatnya adalah peserta didik yang mempunyai tabiat yang kurang baik dan faktor keluarga, faktor lingkungan masyarakat yang kurang mendukung.

\section{Saran}

Saran dalam penelitian ini agar, dapat menjadikan sebagai bahan masukan bagi SD Negeri 071154 Anaoma Kecamatan Alasa dalam rangka mensukseskan program peran guru dalam membentuk karakter siswa Kelas III SD Negeri 071154 Anaoma Kecamatan Alasa, yaitu SD Negeri 071154 Anaoma Kecamatan Alasa agar selalu mengembangkan pendidikan dalam membentuk karakter siswa, sekolah juga harus mampu menjalin kerjasama serta memberi wawasan terhadap orang tua siswa, khususnya yang masih ada problem keluarga. Sehingga mereka memiliki kesadaran tinggi untuk memperhatikan pendidikan anaknya serta ikut berpartisipasi dalam meningkatkan kedisiplinannya. Serta memberikan wawasan-wawasan yang lebih luas tentang wacana dan permasalahan yang terjadi pada kemajemukan masyarakat umum. Sehingga siswa mampu melihat dan mengerti mana yang harus dijauhi untuk memupuk karakter siswa sejak dini.

\section{Referensi}

Arifin, Muzzayyin. 2003. Kapita Selekta Pendidikan Islam. Surabaya: Al Ikhlas.

Arikunto, Suharsimi. 2007. Manajemen Penelitian. Jakarta: Rineka Cipta.

Asmani, Jamal Ma'mur. 2011. Buku Panduan Internalisasi Pendidikan Karakter di Sekolah. Yogyakarta: DIVA Press.

Dharma Kesuma, dkk. 2011. Pendidikan Karakter: Kajian Teori dan Praktis di Sekolah. Bandung: PT Remaja Rosdakarya.

Fitri, Agus Zainal (2012) Pendidikan Karakter Berbasis Nilai\&Etika Di Sekolah, Jogjakarta: Ar-Ruzz Media

Furqon. 1997. Statistik Terapan untun Penelitian. Alfabeta: Bandung 
Hulu, $Y$

Ghufron, Anik. 2010. "Integrasi Nilai-Nilai Karakter Bangsa pada Kegiatan Pembelajaran" Jurnal Ilmiah Pendidikan, (Online), Edisi Khusus Dies Natalis UNY Tahun XXIX, ISSN: 0216-1370 (http://uny.ac.id, diunduh 02 Maret 2015).

Mulyasa, Enco. 2008. Menjadi Guru profesional Menciptakan Pembelajaran Kreatif dan Menyenangkan. Bandung: Remaja Rosdakarya

Putra, Nusa. 2011. Penelitian Kualitatif: Proses dan Aplikasi. Jakarta: Indeks.

Sarosa, Samiaji. 2011. Penelitian Kualitatif Dasar-Dasar. Jakarta: Indeks.

Sugiyono. 2014. Memahami Penelitian Kualitatif. Bandung: Alfabeta.

Sukmadinata, N. S. 2012. Metode Penelitian Pendidikan. Bandung: PT Remaja Rosdakarya. 